Article

\title{
Spatiotemporal Trends Observed in 20 Years of Posidonia oceanica Monitoring along the Alicante Coast, Spain
}

\author{
Fabio Blanco-Murillo ${ }^{1,2, * \mathbb{D}}$, Santiago Jimenez-Gutierrez ${ }^{3}$, Joaquín Martínez-Vidal ${ }^{3}$, Juan Eduardo Guillén ${ }^{3}$ \\ and Jose Luis Sánchez-Lizaso ${ }^{1}$ (D)
}

Citation: Blanco-Murillo, F.; Jimenez-Gutierrez, S.; Martínez-Vidal, J.; Guillén, J.E.; Sánchez-Lizaso, J.L. Spatiotemporal Trends Observed in 20 Years of Posidonia oceanica Monitoring along the Alicante Coast, Spain. Water 2022, 14, 274. https:/ / doi.org/10.3390/w14030274

Academic Editors: Jongkwon Im, Xuwang Zhang, Laura Bulgariu,

Christos S. Akratos and

Francisco Osorio

Received: 30 November 2021

Accepted: 7 January 2022

Published: 18 January 2022

Publisher's Note: MDPI stays neutral with regard to jurisdictional claims in published maps and institutional affiliations.

Copyright: (C) 2022 by the authors. Licensee MDPI, Basel, Switzerland. This article is an open access article distributed under the terms and conditions of the Creative Commons Attribution (CC BY) license (https:// creativecommons.org/licenses/by/ $4.0 /)$.
1 Department of Marine Sciences and Applied Biology, University of Alicante, P.O. Box 99, 03080 Alicante, Spain; jl.sanchez@ua.es

2 Programa de Doctorado Interdisciplinario en Ciencias Ambientales, Facultad de Ciencias Naturales y Exactas, Universidad de Playa Ancha, Valparaíso 2340000, Chile

3 Instituto de Ecología Litoral, 03560 El Campello, Spain; s.jimenez@ecologialitoral.com (S.J.-G.); j.martinez@ecologialitoral.com (J.M.-V.); j.guillen@ecologialitoral.com (J.E.G.)

* Correspondence: fabio.blanco@ua.es

\begin{abstract}
Posidonia oceanica meadows, known to be valuable marine ecosystems, have been reported to be in decline as a result of human activities in recent decades. However, it is still controversial if this decline is a global phenomenon or it is caused by specific disturbances related to human development at a local scale. In order to evaluate changes in P. oceanica meadows, in this study, monitoring data obtained at 14 stations along the Mediterranean coast near Alicante, Spain, over a 20-year period were analyzed. Field data were obtained through the citizen science project POSIMED, which had the aim of carrying out annual monitoring of both shallow and deep P. oceanica meadows along the coast near Alicante and determining whether their ecological status was changing over time. The percentage cover of living $P$. oceanica and dead matte and shoot density data were used to assess the ecosystem status and to determine whether there had been an overall regional decline in seagrass over the 20-year period. Both cover and density data showed a significant positive trend at most locations. However, the amount of dead matte was noted to slightly increase with time while six shallow and one deep station showed a negative P. oceanica cover trend, indicating that in certain locations meadow regression might be taking place. Shoot density decreased with depth and increased with the amount of rock cover; its correlation with the dead matte percentage was unclear, which probably means that a range of different factors can result in the presence of dead plants. These results support the idea that local disturbances are the cause of seagrass decline in the Mediterranean, thus demonstrating the need for management plans that focus on local stressors of $P$. oceanica meadows at specific locations. Long-term, large-scale monitoring allows the ecosystem status in the western Mediterranean to be assessed; however, local disturbances can also affect specific locations.
\end{abstract}

Keywords: seagrass long-term dynamics; environmental monitoring; citizen science; seagrass meadows; seagrass conservation; population dynamics; western Mediterranean seagrass

\section{Introduction}

Seagrass meadows are identified as ecosystems that provide a wide range of both environmental and socioeconomic services in coastal areas around the world, such as primary production, supporting fisheries or sediment stabilization [1-4]. The Mediterranean Sea plays a central role the marine phanerogam Posidonia oceanica [5-7]. This plant, which is endemic to the Mediterranean and is an excellent bioindicator of the coastal environment due not only to its longevity, slow growth rate and wide distribution along the Mediterranean coast but also because of its sensitivity to environmental stressors [8-11]. In fact, this species has shown to rapidly respond to impacts, e.g., pollutant bioaccumulation, physiological responses to temperature and salinity variations, and low survival rate due water quality loss [5,12-16]. 
P. oceanica meadows provide a variety of ecosystem services [5,17], which include high rates of primary production [7], oxygen production, and carbon dioxide storage [18,19]. As a habitat, several species are directly or indirectly dependent on these meadows, and coastal fisheries are significantly supported by them $[1,20]$. P. oceanica meadows also contribute to coastal sedimentary dynamics as they reduce the energy of waves and protect the coastline from erosion, both as the living matte and banquettes formed by the natural accumulations of dead leaves in the shore [21,22]. For these reasons, the species is currently protected by the European Union as a priority habitat by the Habitat Directive 92/43/EEC and as a bioindicator by the Marine Strategy Framework Directive 2008/56/EC.

Given the relevance of $P$. oceanica meadows to the coastal environment and the range of anthropogenic and natural impacts that they suffer [23-28], it is of great importance to assess ecological status and change over time for these ecosystems. In fact, coastal development, marine pollution, global warming, and alien species in coastal areas have caused the decline of marine angiosperms worldwide [23,27-29], with P. oceanica among them, and many studies have reported a general regression of $P$. oceanica meadows due mainly to anthropogenic disturbances [29].

$P$. oceanica, such as other seagrass species, has been considered to be in a general decline, and large-scale studies throughout the Mediterranean basin have reported a general decline of these ecosystems in the last decades [28-34]. However, other recent studies have shown that the decline in P. oceanica is slowing down or even stabilizing [31-36], and the authors consider that the decline is not a global process but is caused by local disturbances. The main challenge in assessing the temporal changes in P. oceanica meadows is the species' slow growth rate [32], as it requires several years of data to properly estimate trends of these ecosystems. To this aim, data from two decades of P. oceanica monitoring were used to determine if there is evidence of a general decline in shallow meadows of the SE Spanish coast.

This study had two main objectives:

- To analyze the evolution of $P$. oceanica cover, dead matte, and shoot density between 2002 and 2021 in shallow and deep meadows at 14 locations near Alicante, Spain, using the data from the POSIMED citizen science network.

- To determine which environmental factors influence general trends in these descriptors over time.

\section{Materials and Methods}

The study area included the coastline of Alicante province, with 14 stations along $200 \mathrm{~km}$ from Dénia to Campoamor (Figure 1).

The POSIMED monitoring program started in 2002. Since then, annual monitoring has been carried out until 2021. However, because of logistical and financial problems, not all locations were sampled every year (Table 1 ). Percentage cover and shoot density data were collected during the summer months (July-September) by researchers and supervised trained volunteers.

Among descriptors used to determine the ecological status of seagrass meadows, the two most commonly used are percentage cover and shoot density, as mentioned above. These descriptors have also been shown to provide accurate assessments of seagrass status at the population level while being relatively easy to measure [8,34-37]. Both the researchers and volunteers made in situ measurements during scuba dives. In order to assess percentage cover, $25-\mathrm{m}$ random linear transects were made. In each transect, a distinction was made between living P. oceanica meadow, dead P. oceanica or dead matte, rock, sand, and other macrophytes. The percentage cover $(\% \mathrm{C})$ was then calculated as follows.

$$
\% \mathrm{C}=100 \times \frac{\text { Distance }(\mathrm{m}) \text { covered by P. oceanica }}{25}
$$

The same method was used to calculate dead matte cover. Shoot density was determined by using a $40 \mathrm{~cm} \times 40 \mathrm{~cm}$ steel quadrat and counting the number of living 
P. oceanica shoots and then extrapolating density per square meter. At each station, samples were taken at two depths, which varied depending on local topography. "Shallow" sampling was performed close to the meadow's upper limit at depths between 3.5 and $6 \mathrm{~m}$; "deep" samples were obtained at depths between 7 and $14 \mathrm{~m}$. At each station and time, nine observations of both descriptors were made. This produced a total of approximately 2400 measurements for 20 years of seagrass monitoring.

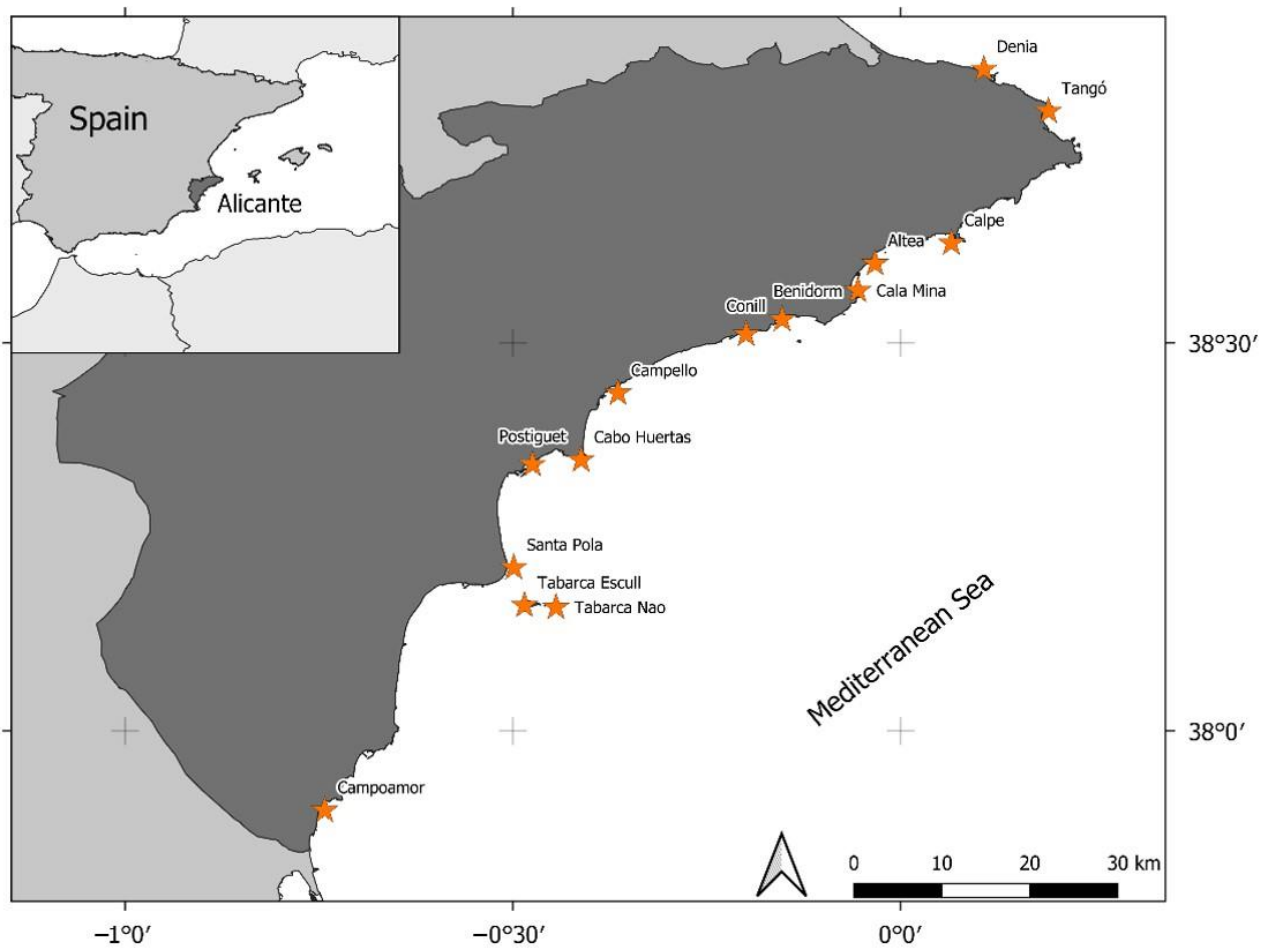

Figure 1. Map of the coast of Alicante province (eastern Spain) with 14 sampling stations.

Table 1. Stations and years where the monitoring took place.

\begin{tabular}{|c|c|c|c|c|c|c|c|c|c|c|c|c|c|c|c|c|c|c|c|c|}
\hline Location & 2002 & 2003 & 2004 & 2005 & 2006 & 2007 & 2008 & 2009 & 2010 & 2011 & 2012 & 2013 & 2014 & 2015 & 2016 & 2017 & 2018 & 2019 & 2020 & 2021 \\
\hline Dénia & $x$ & $x$ & & $X$ & $x$ & & $x$ & $x$ & & & & $x$ & & $x$ & $X$ & $X$ & $x$ & $X$ & $X$ & $x$ \\
\hline Tangó & & & & & & & & & & & & $X$ & $X$ & $x$ & $X$ & $X$ & $X$ & $x$ & $X$ & $X$ \\
\hline Calpe & $X$ & $x$ & $X$ & $x$ & $X$ & $X$ & $X$ & $x$ & $X$ & $X$ & & $X$ & $X$ & $X$ & $X$ & $X$ & $X$ & $X$ & $x$ & $X$ \\
\hline Altea & $X$ & $x$ & $X$ & $X$ & $X$ & $X$ & $X$ & $x$ & $X$ & $x$ & & $X$ & $X$ & $X$ & $X$ & $X$ & $X$ & $x$ & $X$ & $X$ \\
\hline Cala Mina & & & $x$ & $x$ & $x$ & $x$ & $x$ & $x$ & $x$ & $x$ & & $x$ & $x$ & $x$ & $x$ & $x$ & $x$ & $x$ & $x$ & $x$ \\
\hline Benidorm & $X$ & $x$ & $X$ & $x$ & $X$ & $x$ & & $x$ & $x$ & $X$ & $X$ & $x$ & $X$ & $X$ & $X$ & $X$ & $X$ & $X$ & $X$ & $X$ \\
\hline Conill & & & $x$ & $x$ & & & $X$ & $x$ & $x$ & $x$ & & $x$ & $x$ & $x$ & $x$ & $x$ & $x$ & $x$ & $x$ & $x$ \\
\hline Campello & $X$ & $X$ & $x$ & $x$ & & $X$ & $X$ & $x$ & & $x$ & $X$ & $x$ & $X$ & $x$ & $X$ & $x$ & $x$ & $x$ & $x$ & $X$ \\
\hline $\begin{array}{l}\text { Cabo } \\
\text { Huertas }\end{array}$ & & $X$ & $x$ & $X$ & $X$ & $X$ & $X$ & & $X$ & $x$ & $x$ & $x$ & $x$ & $x$ & $x$ & $x$ & $x$ & $x$ & $x$ & $x$ \\
\hline Postiguet & $X$ & $X$ & $X$ & $x$ & $X$ & $x$ & $X$ & $x$ & $X$ & $x$ & & & $X$ & $X$ & $x$ & $X$ & $X$ & $x$ & $X$ & $X$ \\
\hline Santa Pola & $x$ & $x$ & $x$ & $x$ & $x$ & $x$ & $x$ & $x$ & $x$ & $x$ & & $x$ & $x$ & $x$ & $x$ & $x$ & $x$ & $x$ & $x$ & $x$ \\
\hline $\begin{array}{l}\text { Escull } \\
\text { Negre }\end{array}$ & $X$ & $X$ & $X$ & $X$ & $X$ & $X$ & $X$ & $X$ & $X$ & $X$ & $x$ & $X$ & $X$ & $x$ & $X$ & $X$ & $X$ & & $X$ & $X$ \\
\hline Nao & $x$ & $X$ & $X$ & $x$ & $X$ & $x$ & $X$ & $x$ & $x$ & $X$ & & $X$ & $X$ & $x$ & $X$ & $X$ & $x$ & $x$ & $X$ & $x$ \\
\hline Campoamor & & & & & & & & & & & & & & $x$ & $X$ & & $X$ & $X$ & $X$ & $x$ \\
\hline
\end{tabular}

The trends in shoot density, P. oceanica cover, and dead matte cover over time were analyzed. Using density and cover data from every location, the influence of depth was tested as the effect of the rocky substrate and the presence of dead matte on shoot density were also assessed. P. oceanica cover and shoot density trends at each station a depth 
("shallow" and "deep") were also analyzed separately to assess spatial variability of both descriptors through time.

Linear regression models were used to analyze patterns and significant correlations between variables; general additive models (GAM) were used when nonlinear behaviors were found. A Kolmogorov-Smirnov test was used to assess normality of the data, and transformations were made when needed.

\section{Results}

Linear regression models showed that there were significant increments of shoot density and cover data as well as for dead matte (Figure 2).

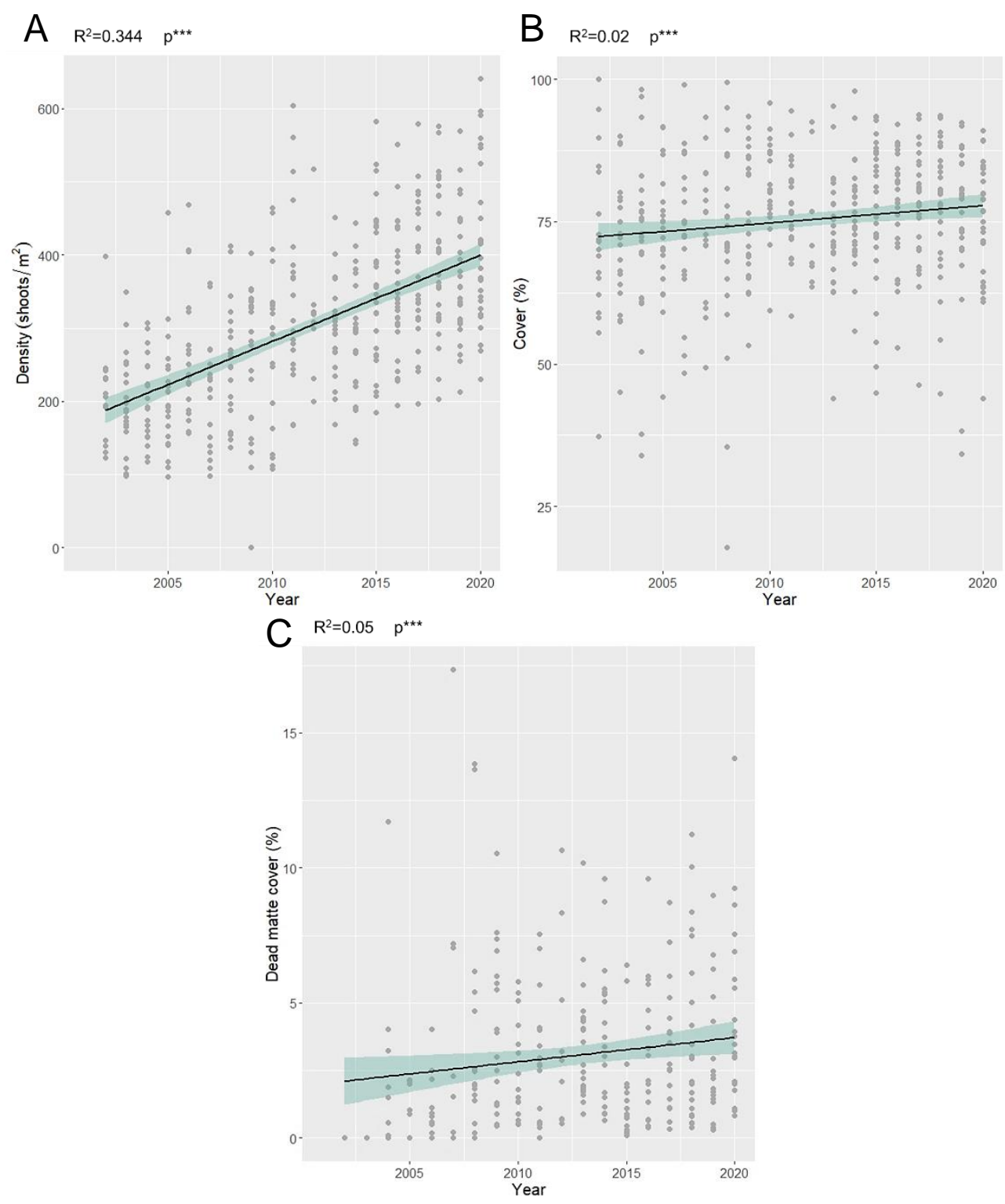

Figure 2. Trends in the shoot density (A), percentage of P. oceanica cover (B), and percentage of dead matte (C) over time. Fitted lines from generalized additive models are presented with $95 \%$ confidence intervals. Coefficient of determination $\left(R^{2}\right)$ and needed transformations are shown. Results of linear regression: ${ }^{* * *}=p<0.005$.

As shown in Figure 3, shoot density decreases with depth and increases with the amount of rock cover, whereas no correlation is observed with dead matte cover. A nonlinear relationship was noted between $P$. oceanica cover and depth, with the maximum amount of cover occurring at intermediate depths between 7 and $10 \mathrm{~m}$. 

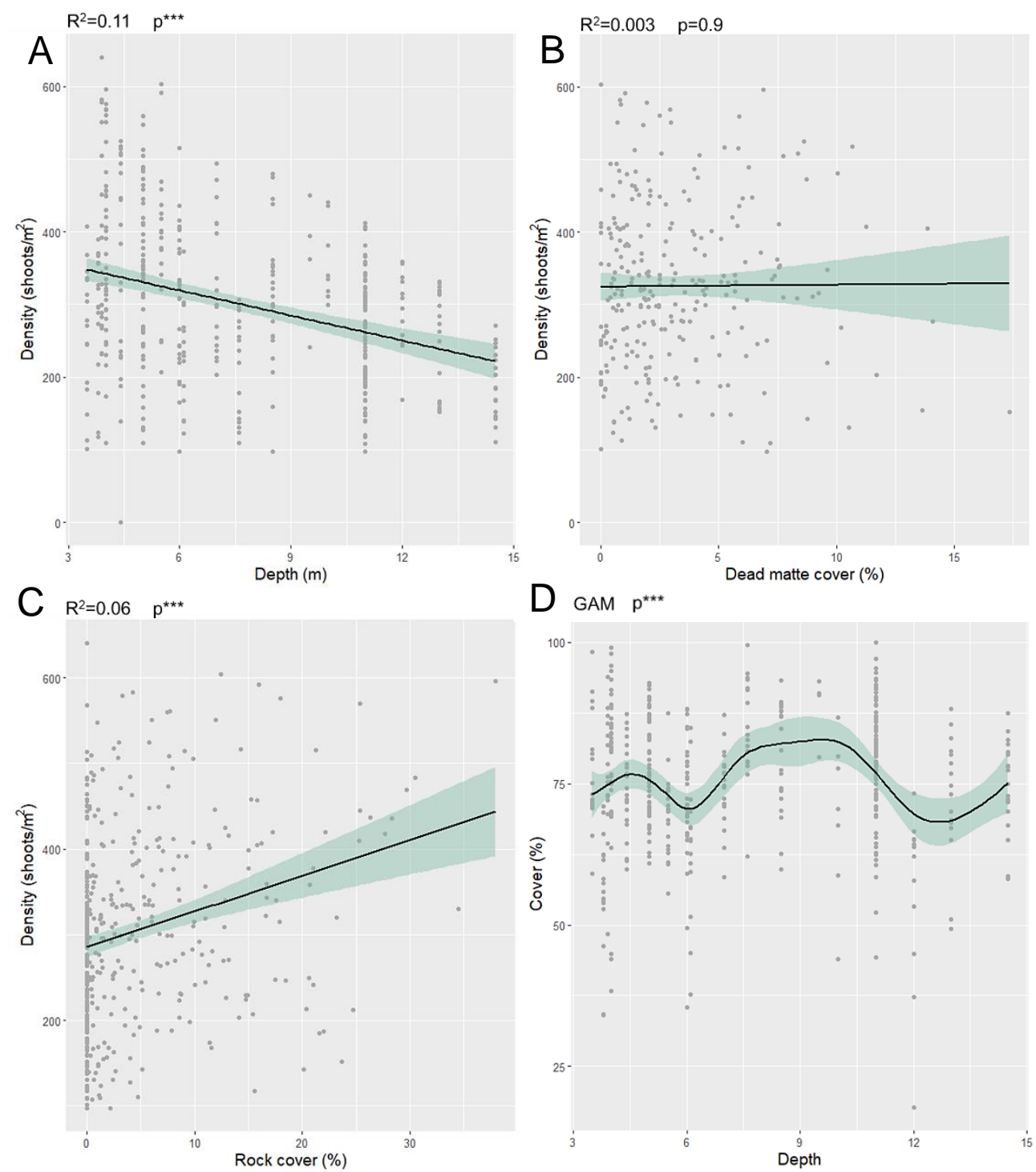

Figure 3. Linear regression between shoot density and (A) depth, $(\mathbf{B})$ dead matte cover, and (C) rock cover; (D) GAM model showing the change of P. oceanica cover with depth. Fitted lines from generalized additive models are presented with $95 \%$ confidence intervals. Coefficient of determination $\left(R^{2}\right)$ and needed transformations are shown. Results of linear regression: ${ }^{* *}=p<0.005$.

Shoot density and P. oceanica cover at each of the monitoring locations exhibit a generally increasing trend (Table 2). Moreover, a significant upward trend was observed in the shoot density at 17 out of 28 locations; the only case where there is a noted decrease is the shallow meadow at Conill, and, even here, this trend is deemed insignificant. There is a significant upward trend in the P. oceanica cover at three shallow and six deep meadows. At one deep and seven shallow location, this trend is downward; however, at none of these locations was the trend significant (Figure 4). 
Table 2. Trends in P. oceanica cover and shoot density with time for different locations and depths. Trendline slope: "+": variable increasing with time; "-": variable decreasing with time. Significant results $(p<0.05)$ are shown in bold.

\begin{tabular}{|c|c|c|c|c|c|}
\hline \multirow{2}{*}{ Location } & \multirow{2}{*}{ Depth } & \multicolumn{2}{|c|}{ Shoot Density } & \multicolumn{2}{|c|}{ P. oceanica Cover } \\
\hline & & Trend & $p$-Value & Trend & $p$-Value \\
\hline Dénia & Shallow & + & 0.001 & - & 0.919 \\
\hline Dénia & Deep & + & 0.001 & + & 0.285 \\
\hline Tangó & Shallow & + & 0.38 & - & 0.860 \\
\hline Tangó & Deep & + & 0.834 & + & 0.01 \\
\hline Calpe & Shallow & + & 0.253 & + & 0.217 \\
\hline Calpe & Deep & + & 0.176 & + & 0.001 \\
\hline Altea & Shallow & + & 0.009 & + & 0.933 \\
\hline Altea & Deep & + & 0.185 & + & 0.266 \\
\hline Cala Mina & Shallow & + & 0.013 & + & 0.494 \\
\hline Cala Mina & Deep & + & 0.120 & + & 0.197 \\
\hline Benidorm & Shallow & + & 0.001 & - & 0.952 \\
\hline Benidorm & Deep & + & 0.0005 & + & 0.014 \\
\hline Conill & Shallow & + & 0.354 & + & 0.741 \\
\hline Conill & Deep & - & 0.886 & + & 0.031 \\
\hline Campello & Shallow & + & 0.002 & + & 0.009 \\
\hline Campello & Deep & + & 0.013 & - & 0.057 \\
\hline $\begin{array}{l}\text { Cabo } \\
\text { Huertas }\end{array}$ & Shallow & + & 0.0004 & + & 0.191 \\
\hline $\begin{array}{l}\text { Cabo } \\
\text { Huertas }\end{array}$ & Deep & + & 0.001 & + & 0.190 \\
\hline Postiguet & Shallow & + & 0.0003 & - & 0.509 \\
\hline Postiguet & Deep & + & 0.0001 & + & 0.327 \\
\hline Santa Pola & Shallow & + & 0.0003 & + & 0.506 \\
\hline Santa Pola & Deep & + & 0.0008 & + & 0.300 \\
\hline Escull Negre & Shallow & + & $8.67 \times 10^{-5}$ & + & 0.02 \\
\hline Escull Negre & Deep & + & $6.62 \times 10^{-5}$ & + & 0.315 \\
\hline Tabarca Nao & Shallow & + & $3.31 \times 10^{-6}$ & + & 0.06 \\
\hline Tabarca Nao & Deep & + & 0.067 & + & 0.906 \\
\hline Campoamor & Shallow & + & 0.244 & - & 0.672 \\
\hline Campoamor & Deep & + & 0.219 & + & 0.011 \\
\hline
\end{tabular}

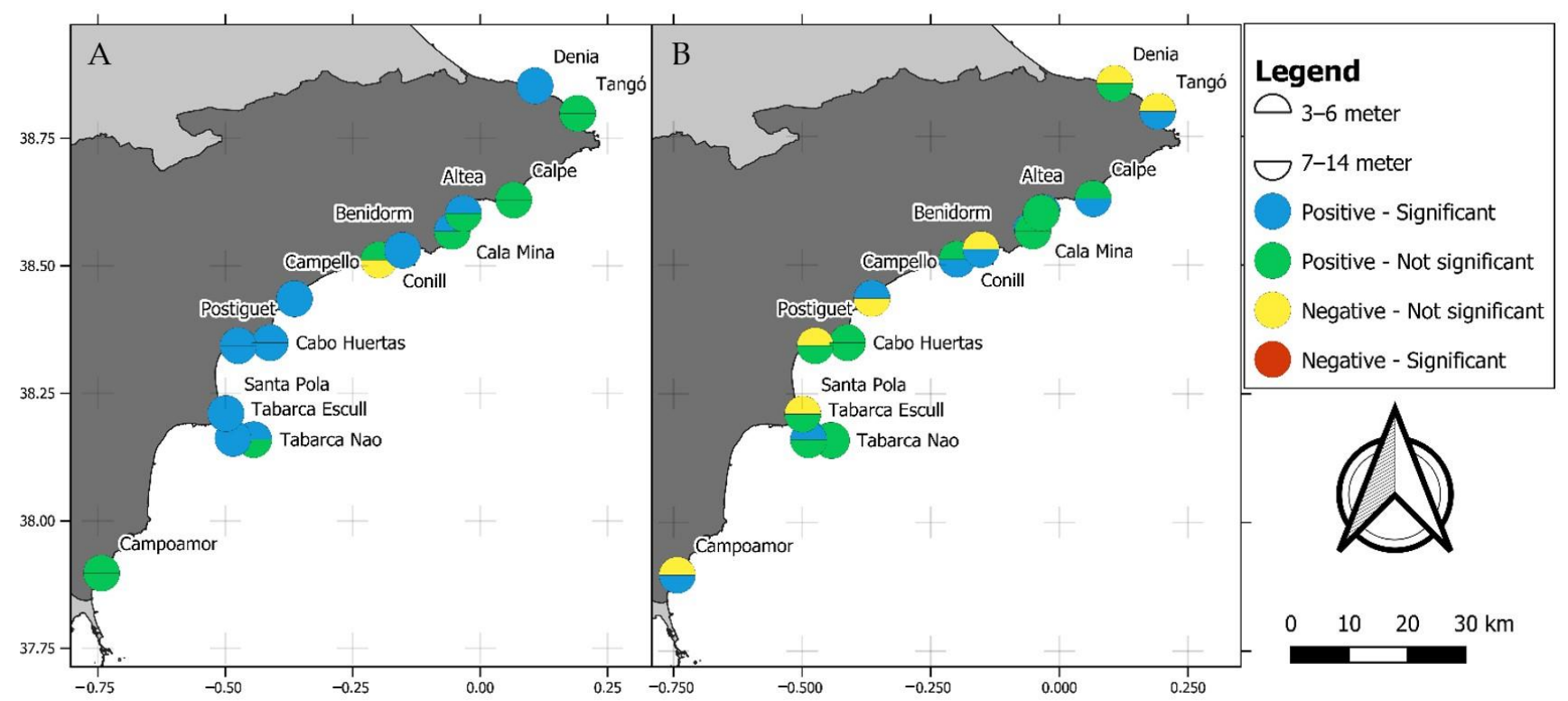

Figure 4. Trends in (A) shoot density and (B) P. oceanica cover for different monitoring stations representing their global trend (positive or negative) and linear regression results. 


\section{Discussion}

In recent decades, $P$. oceanica meadows have been reported to be in decline in many regions of France, Italy, and Spain [29,30,38], including the Alicante region [39]. However, in previous studies, researchers have considered that this is not a global phenomenon $[32,33,40]$. This apparent contradiction can be explained by processes that are occurring at the local scale [41].

In this study, it has been shown that, overall, the density of P. oceanica tends to increase and its cover is stable within the study area, meaning that there is no overall decline in the analyzed metrics at the locations where observations were made. These results confirm the recent reversal of the decline previously suffered by European seagrass meadows [31] and, therefore, support the idea that the decline of P. oceanica meadows is caused by local disturbances rather than global impacts [32,33].

A general increase in dead matte cover has been previously reported, which means a reduction in the amount of meadow [42,43]. Our results show a moderate, but significant, increase in dead matte cover throughout the study period, which indicates that, although there is no evidence of a decline in P. oceanica, disturbances that are damaging the meadows are occurring.

The decrease in shoot density with depth is a well-examined phenomenon and is caused mainly by light limitation [44], and P. oceanica has shown to effectively respond to different light intensities, thus physiologically adapting to changes in available light [45]. However, as shallow stations show more significant positive trends than deep stations, this could indicate that deeper and less dense meadows could be more vulnerable to environmental impacts [42]. Regarding data for P. oceanica cover, shallower meadows tend to be patchier, and the cover is interrupted naturally due to coastal dynamics and bottom heterogeneity $[46,47]$. GAM analysis showed that the area colonized by P. oceanica is higher and most stable between depths of 7 and $10 \mathrm{~m}$ and decreases onshore and offshore. Both descriptors showed natural behavior according to depth [34].

It was also found that shoot density is independent of the amount of dead matte cover, which could be taken as indicating the existence of a variety of impacts affecting the meadows. Low shoot densities could be an early indicator of meadow regression due to a decline in water quality, which might ultimately result in an increase in dead matte cover and meadow fragmentation [22]. On the other hand, high meadow densities where dead matte is also present could mean that physical impacts are the cause of regression. Physical damage, such as that caused by boat anchoring, can drastically reduce seagrass' surface by directly uprooting meadow fragments $[46,48]$ without initially affecting the density of the remaining meadow. Currently, with the exception of designated marine reserves, boat anchoring is not forbidden within the seagrass meadows near Valencia. In fact, the percentage of $P$. oceanica meadows that lies within the protected areas in this region is relatively low [49] although most of the observation sites do have a limited degree of protection and lie within designated Sites of Community Importance or Special Areas of Conservation. However, only sites at Escull Negre and Nao (which lie within the Tabarca Marine Reserve) have controls on fishing and anchoring. Although a positive trend was noted at most stations, this does not appear to be related to the existence of protected areas since most of the observation sites do not lie within areas that enjoy a high degree of protection and suffer from the effects of activities such as boat anchoring, especially in a highly touristic area such as Alicante.

At certain sites (Posiguet, Santa Pola, and Conill), a moderate decline in shallow meadows cover was observed although there was an opposite trend in terms of shoot density. This might be a result of earlier, extensive fragmentation of the meadows due to natural or anthropogenic impacts and a subsequent, recent improvement in environmental conditions. The fragmented meadows could be losing cover because isolated patches are disappearing, whereas the more intact parts are maintaining or increasing their density. Structural dynamics and seascape changes are complex and should, thus, be assessed at a lower spatial scale $[34,46]$. 
When interpreting the results of this work, the wide range of descriptors used to determine meadow health should be considered [8]. In general, the seagrass meadow losses that have been reported in other studies were related to the extent of the meadows (presence, areal extent, and depth limit) rather than to the structural metrics that were analyzed in this study (percentage cover and shoot density) [31]. This observation confirms the need for developing accurate meadow maps and for expanding monitoring to complement these data related to the meadows' extent and to determine whether the meadows in a particular area are declining by a change in the upper and lower limits and its magnitude since our monitoring is restricted to intermediate depth meadows.

The key to seagrass conservation is the development of effective management measures that stop ecosystem decline and allow its recovery [50]. In fact, effective management is already having a positive impact on seagrasses [31]; however, there are still many methods in which the management of these ecosystems could be improved [51] and knowledge of long-term dynamics may be an essential tool for this issue. Although P. oceanica is one of the most-studied seagrass species in the world [34], long-term effects are still being assessed $[29,40,52,53]$. In order to effectively assess the status of $P$. oceanica ecosystems, long-term studies are needed because of the slow growth rate of this species, which show changes on the scale of decades, especially for population descriptors such as shoot density and percentage cover. Moreover, due to the potential effect of genetic diversity on the tolerance and resilience of $P$. oceanica to certain impacts [54], spatial variability should be considered when developing seagrass monitoring on the long term.

This work also demonstrates the value of the contributions made by volunteers to longterm monitoring programs. Citizen science allows researchers to increase their sampling power [55-57], making it possible to collect a greater number of data. Moreover, in addition to scientific aims, another important objective was achieved by the project; that is, it raised the awareness of the local population through participation and provided tools that allowed them to understand the relevance of marine ecosystems and the threats that they facespecifically, in this case, those faced by P. oceanica meadows.

\section{Conclusions}

Both $P$. oceanica cover and shoot density show a positive trend at the locations where observations were made. No evidence of a regression process was found in the upper limit of the studied meadows. Three locations resented a non-significant decline in bottom cover while density increased, probably due to physical impacts such as anchoring. This trend was independent of the existence of protection figures.

Dead matte also presented a moderate increase through time, meaning that there are stressors affecting $P$. oceanica meadows, although this damage seems to be below the recovery capacity in most locations. P. oceanica shoot density is influenced by topographic factors such as depth and the amount of rock cover but is independent of the dead matte cover possibly because meadows are affected by different disturbances, where density remaining meadow might not always be equally affected.

Overall, there is no evidence of decline in the P. oceanica meadows in the study area in the last 20 years, supporting the idea of this species regression occurring at a local scale instead of being caused by global processes.

Author Contributions: Conceptualization, F.B.-M., S.J.-G., J.M.-V. and J.E.G.; methodology, F.B.-M., S.J.-G. and J.M.-V.; validation, F.B.-M., S.J.-G., J.M.-V., J.E.G. and J.L.S.-L.; writing-original draft preparation, F.B.-M. and J.L.S.-L.; writing-review and editing, F.B.-M., S.J.-G., J.M.-V. and J.L.S.-L.; project administration and funding acquisition, S.J.-G., J.M.-V. and J.E.G. All authors have read and agreed to the published version of the manuscript.

Funding: This research received no external funding.

Institutional Review Board Statement: Not applicable.

Informed Consent Statement: Not applicable. 


\begin{abstract}
Acknowledgments: We acknowledge the friendly cooperation of Diputación Provincial de Alicante, the Marine Reserve of Tabarca, the Policía Local de Alicante, and the Policía Local de Benidorm. We would also like to thank all volunteers involved in the fieldwork of POSIMED project for their invaluable help. We also thank the reviewers of this paper who really helped us to improve the original manuscript.
\end{abstract}

Conflicts of Interest: The authors declare no conflict of interest. The funders had no role in the design of the study; in the collection, analyses, or interpretation of data; in the writing of the manuscript; or in the decision to publish the results.

\title{
References
}

1. de los Santos, C.; Scott, A.; Arias-Ortiz, A.; Jones, B.; Kennedy, H.; Mazarrasa, I.; McKenzie, L.; Nordlund, L.M.; de la Torre-Castro, M. Seagrass ecosystem services: Assessment and scale of benefits. In Out of the Blue: The Value of Seagrasses to the Environment and to People; Potouroglou, M., Grimsditch, G., Weatherdon, L., Lutz, S., Eds.; United Nations Environment: Nairobi, Kenya, 2020 ; p. 95.

2. Tuya, F.; Haroun, R.; Espino, F. Economic assessment of ecosystem services: Monetary value of seagrass meadows for coastal fisheries. Ocean Coast. Manag. 2014, 96, 181-187. [CrossRef]

3. Dewsbury, B.M.; Bhat, M.; Fourqurean, J.W. A review of seagrass economic valuations: Gaps and progress in valuation approaches. Ecosyst. Serv. 2016, 18, 68-77. [CrossRef]

4. Nordlund, L.M.; Jackson, E.L.; Nakaoka, M.; Samper-Villarreal, J.; Beca-Carretero, P.; Creed, J.C. Seagrass ecosystem servicesWhat's next? Mar. Pollut. Bull. 2018, 134, 145-151. [CrossRef] [PubMed]

5. Boudouresque, C.F.; Bernard, G.; Bonhomme, P.; Charbonnel, E.; Diviacco, G.; Meinesz, A.; Pergent, G.; Pergent-Martini, C.; Ruitton, S.; Tunesi, L.; et al. Protection and Conservation of Posidonia oceanica Meadows; RAMOGE and RAC/SPA: Tunis, Tunisia, 2012; ISBN 2-905540-31-1.

6. $\quad$ Boudouresque, C.F.; Meinesz, A. Découverte de L'herbier de Posidonies; Cahier Parc National Port-Cros: Hyères, France, 1982; Volume 4, pp. 1-79.

7. Sánchez-Lizaso, J.L. Estudio de Ia Pradera de Posidonia oceanica (L.) Delile de la Reserva Marina de Tabarca (Alicante): Fenología y Producción Primaria; Universidad de Alicante: Alicante, Spain, 1993.

8. Pergent-Martini, C.; Leoni, V.; Pasqualini, V.; Ardizzone, G.D.; Balestri, E.; Bedini, R.; Belluscio, A.; Belsher, T.; Borg, J.; Boudouresque, C.F.; et al. Descriptors of Posidonia oceanica meadows: Use and application. Ecol. Indic. 2005, 5, 213-230. [CrossRef]

9. Romero, J.; Martínez-Crego, B.; Alcoverro, T.; Pérez, M. A multivariate index based on the seagrass Posidonia oceanica (POMI) to assess ecological status of coastal waters under the water framework directive (WFD). Mar. Pollut. Bull. 2007, 55, 196-204. [CrossRef] [PubMed]

10. Fernández-Torquemada, Y.; Díaz-Valdés, M.; Colilla, F.; Luna, B.; Sánchez-Lizaso, J.L.; Ramos-Esplá, A.A. Descriptors from Posidonia oceanica (L.) Delile meadows in coastal waters of Valencia, Spain, in the context of the EU Water Framework Directive. ICES J. Mar. Sci. 2008, 65, 1492-1497. [CrossRef]

11. McKenzie, L.J.; Nordlund, L.M.; Jones, B.L.; Cullen-Unsworth, L.C.; Roelfsema, C.; Unsworth, R.K.F. The global distribution of seagrass meadows. Environ. Res. Lett. 2020, 15, 074041. [CrossRef]

12. Roca, G.; Alcoverro, T.; de Torres, M.; Manzanera, M.; Martínez-Crego, B.; Bennett, S.; Farina, S.; Pérez, M.; Romero, J. Detecting water quality improvement along the Catalan coast (Spain) using stress-specific biochemical seagrass indicators. Ecol. Indic. 2015, 54, 161-170. [CrossRef]

13. Bonanno, G.; Di Martino, V. Trace element compartmentation in the seagrass Posidonia oceanica and biomonitoring applications. Mar. Pollut. Bull. 2017, 116, 196-203. [CrossRef]

14. Jordà, G.; Marbà, N.; Duarte, C.M. Mediterranean seagrass vulnerable to regional climate warming. Nat. Clim. Chang. 2012, 2, 821-824. [CrossRef]

15. Fernández-Torquemada, Y.; Sánchez-Lizaso, J.L. Effects of salinity on leaf growth and survival of the Mediterranean seagrass Posidonia oceanica (L.) Delile. J. Exp. Mar. Biol. Ecol. 2005, 320, 57-63. [CrossRef]

16. Ruiz, J.M.; Romero, J. Effects of disturbances caused by coastal constructions on spatial structure, growth dynamics and photosynthesis of the seagrass Posidonia oceanica. Mar. Pollut. Bull. 2003, 46, 1523-1533. [CrossRef]

17. Calizza, E.; Costantini, M.L.; Carlino, P.; Bentivoglio, F.; Orlandi, L.; Rossi, L. Posidonia oceanica habitat loss and changes in litter-associated biodiversity organization: A stable isotope-based preliminary study. Estuar. Coast. Shelf Sci. 2013, 135, 137-145. [CrossRef]

18. Boudouresque, C.F.; Pergent, G.; Pergent-Martini, C.; Ruitton, S.; Thibaut, T.; Verlaque, M. The necromass of the Posidonia oceanica seagrass meadow: Fate, role, ecosystem services and vulnerability. Hydrobiologia 2016, 781, 25-42. [CrossRef]

19. Pergent-Martini, C.; Pergent, G.; Monnier, B.; Boudouresque, C.-F.; Mori, C.; Valette-Sansevin, A. Contribution of Posidonia oceanica meadows in the context of climate change mitigation in the Mediterranean Sea. Mar. Environ. Res. 2021, $165,105236$. [CrossRef]

20. Unsworth, R.K.F.; Nordlund, L.M.; Cullen-Unsworth, L.C. Seagrass meadows support global fisheries production. Conserv. Lett. 2019, 12, e12566. [CrossRef] 
21. Gacia, E.; Duarte, C.M. Sediment Retention by a Mediterranean Posidonia oceanica Meadow: The Balance between Deposition and Resuspension. Estuar. Coast. Shelf Sci. 2001, 52, 505-514. [CrossRef]

22. Manca, E.; Cáceres, I.; Alsina, J.M.; Stratigaki, V.; Townend, I.; Amos, C.L. Wave energy and wave-induced flow reduction by full-scale model Posidonia oceanica seagrass. Cont. Shelf Res. 2012, 50-51, 100-116. [CrossRef]

23. Boudouresque, C.F.; Bernard, G.; Pergent, G.; Shili, A.; Verlaque, M. Regression of Mediterranean seagrasses caused by natural processes and anthropogenic disturbances and stress: A critical review. Bot. Mar. 2009, 52, 395-418. [CrossRef]

24. Short, F.T.; Wyllie-Echeverria, S. Natural and human-induced disturbance of seagrasses. Environ. Conserv. 1996, 23, 17-27. [CrossRef]

25. Duarte, C.M. Seagrass ecology at the turn of the millennium: Challenges for the new century. Aquat. Bot. 1999, 65, 7-20. [CrossRef]

26. Hemminga, M.A.; Duarte, C.M. Seagrass Ecology, 1st ed.; Cambridge University Press: Cambridge, UK, 2000; ISBN 978-0-52166184-3.

27. Orth, R.J.; Carruthers, T.J.B.; Dennison, W.C.; Duarte, C.M.; Fourqurean, J.W.; Heck, K.L.; Hughes, A.R.; Kendrick, G.A.; Kenworthy, W.J.; Olyarnik, S.; et al. A Global Crisis for Seagrass Ecosystems. BioScience 2006, 56, 987-996. [CrossRef]

28. Waycott, M.; Duarte, C.M.; Carruthers, T.J.B.; Orth, R.J.; Dennison, W.C.; Olyarnik, S.; Calladine, A.; Fourqurean, J.W.; Heck, K.L.; Hughes, A.R.; et al. Accelerating loss of seagrasses across the globe threatens coastal ecosystems. Proc. Natl. Acad. Sci. USA 2009, 106, 12377-12381. [CrossRef] [PubMed]

29. Telesca, L.; Belluscio, A.; Criscoli, A.; Ardizzone, G.; Apostolaki, E.T.; Fraschetti, S.; Gristina, M.; Knittweis, L.; Martin, C.S.; Pergent, G.; et al. Seagrass meadows (Posidonia oceanica) distribution and trajectories of change. Sci. Rep. 2015, 5, 12505. [CrossRef]

30. Marbà, N.; Duarte, C.; Cebrián, J.; Gallegos, M.; Olesen, B.; Sand-Jensen, K. Growth and population dynamics of Posidonia oceanica on the Spanish Mediterranean coast:elucidating seagrass decline. Mar. Ecol. Prog. Ser. 1996, 137, 203-213. [CrossRef]

31. de los Santos, C.B.; Krause-Jensen, D.; Alcoverro, T.; Marbà, N.; Duarte, C.M.; van Katwijk, M.M.; Pérez, M.; Romero, J.; Sánchez-Lizaso, J.L.; Roca, G.; et al. Recent trend reversal for declining European seagrass meadows. Nat. Commun. 2019, 10, 3356. [CrossRef] [PubMed]

32. González-Correa, J.; Bayle Sempere, J.; Sánchez-Jerez, P.; Valle, C. Posidonia oceanica meadows are not declining globally. Analysis of population dynamics in marine protected areas of the Mediterranean Sea. Mar. Ecol. Prog. Ser. 2007, 336, 111-119. [CrossRef]

33. Guillén, J.E.; Sánchez Lizaso, J.L.; Jiménez, S.; Martínez, J.; Codina, A.; Montero, M.; Triviño, A.; Soler, G.; Zubcoff, J.J. Evolution of Posidonia oceanica seagrass meadows and its implications for management. J. Sea Res. 2013, 83, 65-71. [CrossRef]

34. Abadie, A.; Pace, M.; Gobert, S.; Borg, J.A. Seascape ecology in Posidonia oceanica seagrass meadows: Linking structure and ecological processes for management. Ecol. Indic. 2018, 87, 1-13. [CrossRef]

35. Boudouresque, C.F.; Bernard, G.; Bonhomme, P.; Charbonnel, E.; Diréach, L.L.; Ruitton, S. Monitoring methods for Posidonia oceanica seagrass meadows in Provence and the French Riviera. Sci. Rep. Port-Cros Natl. Park 2007, 22, 17-38.

36. Gobert, S.; Sartoretto, S.; Rico-Raimondino, V.; Andral, B.; Chery, A.; Lejeune, P.; Boissery, P. Assessment of the ecological status of Mediterranean French coastal waters as required by the Water Framework Directive using the Posidonia oceanica Rapid Easy Index: PREI. Mar. Pollut. Bull. 2009, 58, 1727-1733. [CrossRef]

37. Martínez-Crego, B.; Vergés, A.; Alcoverro, T.; Romero, J. Selection of multiple seagrass indicators for environmental biomonitoring Mar. Ecol. Prog. Ser. 2008, 361, 93-109. [CrossRef]

38. Holon, F.; Boissery, P.; Guilbert, A.; Freschet, E.; Deter, J. The impact of 85 years of coastal development on shallow seagrass beds (Posidonia oceanica L. (Delile)) in South Eastern France: A slow but steady loss without recovery. Estuar. Coast. Shelf Sci. 2015, 165, 204-212. [CrossRef]

39. Sanchez-Lizaso, J.L.; Guillén, J.E.; Ramos-Esplá, A.A. The regression of Posidonia oceanica meadows in El Campello (SE Iberian Peninsula). Rapp. Commun. CIESM 1990, 32, 7.

40. González-Correa, J.M.; Sanchez-Lizaso, J.L.; Fernández-Torquemada, Y.; Forcada, A. Long-term population dynamics in a healthy Posidonia oceanica meadow. Thalassas 2015, 31, 63-72.

41. Montefalcone, M.; Albertelli, G.; Morri, C.; Bianchi, C.N. Urban seagrass: Status of Posidonia oceanica facing the Genoa city waterfront (Italy) and implications for management. Mar. Pollut. Bull. 2007, 54, 206-213. [CrossRef]

42. Ardizzone, G.; Belluscio, A.; Maiorano, L. Long-term change in the structure of a Posidonia oceanica landscape and its reference for a monitoring plan. Mar. Ecol. 2006, 27, 299-309. [CrossRef]

43. Tamburello, L.; Benedetti-Cecchi, L.; Ghedini, G.; Alestra, T.; Bulleri, F. Variation in the structure of subtidal landscapes in the NW Mediterranean Sea. Mar. Ecol. Prog. Ser. 2012, 457, 29-41. [CrossRef]

44. Dalla Via, J.; Sturmbauer, C.; Schonweger, G.; Sotz, E.; Mathekowitsch, S.; Stifter, M.; Rieger, R. Light gradients and meadow structure in Posidonia oceanica: Ecomorphological and functional correlates. Mar. Ecol. Prog. Ser. 1998, 163, 267-278. [CrossRef]

45. Dattolo, E.; Ruocco, M.; Brunet, C.; Lorenti, M.; Lauritano, C.; D’Esposito, D.; De Luca, P.; Sanges, R.; Mazzuca, S.; Procaccini, G Response of the seagrass Posidonia oceanica to different light environments: Insights from a combined molecular and photophysiological study. Mar. Environ. Res. 2014, 101, 225-236. [CrossRef]

46. Abadie, A.; Gobert, S.; Bonacorsi, M.; Lejeune, P.; Pergent, G.; Pergent-Martini, C. Marine space ecology and seagrasses. Does patch type matter in Posidonia oceanica seascapes? Ecol. Indic. 2015, 57, 435-446. [CrossRef]

47. Pace, M.; Borg, J.A.; Galdies, C.; Malhotra, A. Influence of wave climate on architecture and landscape characteristics of Posidonia oceanica meadows. Mar. Ecol. 2017, 38, e12387. [CrossRef] 
48. La Manna, G.; Donno, Y.; Sarà, G.; Ceccherelli, G. The detrimental consequences for seagrass of ineffective marine park management related to boat anchoring. Mar. Pollut. Bull. 2015, 90, 160-166. [CrossRef] [PubMed]

49. Ruiz, J.M.; Guillén, J.E.; Ramos-Segura, A.; Otero, M.M. Atlas de Praderas Marinas de España; Instituto Español de Oceanografía: Madrid, Spain, 2015.

50. Griffiths, L.L.; Connolly, R.M.; Brown, C.J. Critical gaps in seagrass protection reveal the need to address multiple pressures and cumulative impacts. Ocean Coast. Manag. 2020, 183, 104946. [CrossRef]

51. Montefalcone, M.; Albertelli, G.; Morri, C.; Parravicini, V.; Bianchi, C.N. Legal protection is not enough: Posidonia oceanica meadows in marine protected areas are not healthier than those in unprotected areas of the northwest Mediterranean Sea. Mar. Pollut. Bull. 2009, 58, 515-519. [CrossRef]

52. Leiva-Dueñas, C.; Martínez Cortizas, A.; Piñeiro-Juncal, N.; Díaz-Almela, E.; Garcia-Orellana, J.; Mateo, M.A. Long-term dynamics of production in western Mediterranean seagrass meadows: Trade-offs and legacies of past disturbances. Sci. Total Environ. 2021, 754, 142117. [CrossRef]

53. Leiva-Dueñas, C.; López-Merino, L.; Serrano, O.; Martínez Cortizas, A.; Mateo, M.A. Millennial-scale trends and controls in Posidonia oceanica (L. Delile) ecosystem productivity. Glob. Planet. Chang. 2018, 169, 92-104. [CrossRef]

54. Micheli, C.; D’Esposito, D.; Belmonte, A.; Peirano, A.; Valiante, L.M.; Procaccini, G. Genetic diversity and structure in two protected Posidonia oceanica meadows. Mar. Environ. Res. 2015, 109, 124-131. [CrossRef]

55. Forrester, G.; Baily, P.; Conetta, D.; Forrester, L.; Kintzing, E.; Jarecki, L. Comparing monitoring data collected by volunteers and professionals shows that citizen scientists can detect long-term change on coral reefs. J. Nat. Conserv. 2015, 24, 1-9. [CrossRef]

56. Le Rest, K.; Pinaud, D.; Bretagnolle, V. Volunteer-based surveys offer enhanced opportunities for biodiversity monitoring across broad spatial extent. Ecol. Inform. 2015, 30, 313-317. [CrossRef]

57. Cigliano, J.A.; Meyer, R.; Ballard, H.L.; Freitag, A.; Phillips, T.B.; Wasser, A. Making marine and coastal citizen science matter. Ocean Coast. Manag. 2015, 115, 77-87. [CrossRef] 